\title{
Rafał Opulski
}

ORCID: https://orcid.org/0000-0001-9772-0298

Historical Research Office of the Institute of National Remembrance, Krakow, Poland

\section{Stalinization, de-Stalinization, and re-Stalinization. 1953 behind the "Iron Curtain"}

\author{
“De-Stalinization did not start with Khrushchev's denun- \\ ciation of Stalin in early 1956. \\ The first and the essential act of de-Stalinization was the \\ death of Stalin"
}

Robert C. Tucker ${ }^{1}$

\begin{abstract}
The aim of the article is to present the changesthattook place after the death of Joseph Stalin in 1953 in the Soviet Union and in somecountriesincluded in its "externalempire". The "Iron Curtain", which divided the worldintotwoparts, began to shiftafter the Generalissimo'sdeath and revealed differences in the approach of individualcountries to the „newcourse” announced by Stalin'ssuccessors.

In somecountries, the death of the Kremlindictatorbeganchanges in the policy of the time, in others the methodscharacteristic of Stalinismwerecontinued, whichmeant the activity of anall-powerfulapparatus of repressionseeking real and imagined "enemies", the central authority of unlimitedpower with mass terror and striving for totalcontrol of citizens and allmanifestations of social life. The textpresents the most importantelements of the policy of the Communistparties in the Soviet Union, GDR, Hungary, Czechoslovakia,

1 R. C. Tucker, The Politics of Soviet De-Stalinization, "World Politics" (1957), Vol. 9, No. 4 (Jul.), pp. 561.
\end{abstract}


Romania and Bulgaria in 1953 whichwereconsistent with the process of re-Stalinization, characterized by similarity to governmentsduring the dictator's life and de-Stalinization, thatis, the reversals of methods and toolsknown in the Stalinism period.

\section{Keywords}

Stalinism, newcourse, de-Stalinization, re-Stalinization

One of the most important events of 1953 that had serious consequences not only for the countries behind the "Iron Curtain" was the death of Joseph Stalin on 5 Marchin his KuntsevoDachain the suburbs of Moscow. The following day, this information made the headlines of the newspapers in the Eastern bloc countries."The heart of the greatest man of our time, the companion Joseph Vissaronovich Stalin, stopped beating", read the "Neues Deutschland", the chief press organ of the SED East German communist party. The newspapers quoted the communication released by the Central Committee of the Communist Party of the Soviet Union, which read about the death of "a companion fighter and brilliant continuator of the work of Lenin, wise Leader and Teacher of the Communist Party and the Soviet people." 2 The most important places in the capitals of Central Europe, such as Wenceslas Square in Prague or Alexanderplatz in Berlin, were overflowing with mourners, the radio broadcast funeral music, and in front of the photographs of the "great linguist" honorary guards were held. Despite these manifestations of the cult of the individual, a large part of the society and members of the party apparatus werehoping that the death of the 9dictator would give rise to necessary reforms in the crisis-ridden communist system.

This article outlines the changes which took place in 1953 in the Soviet Union and in some of the countries making up its "external empire", i.e. the GDR, Czechoslovakia, Hungary, Romania, and Bulgaria. ${ }^{3}$ Following the Generalissimo's death, the Iron Curtain, which haddivided the world several years earlier into two parts began to be more see-through and the differences in the approach

${ }^{2}$ Przestało bić serce wodza ludzkości - Wielkiego Stalina, „Trybuna Ludu”, 6.03.1953, p. 1.

${ }^{3}$ The article does not describe events in Poland, which are the subject of detailed considerations in other texts published in the volume. It is worth mentioning, however, that in Poland no attempts were undertaken to introduce the "new course" in 1953. 
of individual countries to the "new course" announced by the successors of Stalin ${ }^{4}$ were made apparent.

\section{The Soviet Union under the rule of Beria and Malenkov}

One of the Gulag physicians described the deceased ruler of the empire as "a tyrant who would have that one huge country by the short hairs, and that the fate of each prisoner was in this way or other tied with the Stalin's own fate". After 5 March, it dawned on many that the system would not survive in its the shape of that time, and the necessary transformation of the regime would affect not only the lives of prisoners, but also ofthose of all citizens. The need for reforms was evidenced by the fact that,even at the funeral of Stalin Georgy Malenkov, his contemporaries surprisingly stated that the two systems - socialist and capitalist - may coexist peacefully. The "new course" in the Soviet Union spanned several levels: structures of power, terror apparatus, economy, andinternal and foreign policies. The changesintroduced in the USSR from that moment were called the 'thaw', the name having been coined by Ilia Ehrenburg's novel or even Beria'sBlitzkrieg, following the well-known French Sovietologist. ${ }^{5}$

After the death of Stalin, collective leadership of the supreme state bodies was introduced, thus dismantling the function of the secretary general of the Communist party of the Soviet Union and separating party and state functions. The key persons in the country were the founder of SMERSH counterintelligence, Lavrentiy Beria, at the head of the powerful Ministry of Internal Affairs, which was in control of the entire apparatus of violence, Malenkov - the new chairman of the Council of Ministers and Nikita Khrushchev - secretary of the Central Committee seeking to take control of the party. Many observers were surprised by the fact that the close associates of Stalin were in fact the driving force behind

${ }^{4}$ Some historians, namely Jerzy Holzer, termed the reforms introduced after the death of Stalin as the "new course". Stalinization is understood as introducing first of all political and economic changes as modelled by the Soviet Union, the activity of an omnipotent apparatus of repression, seeking real and imagined enemies, wielding unlimited power by the central authority as well as mass terror and striving to take over total control over citizens and all manifestations of social life. Re-Stalinization means a return to the governance when under the dictatorship, and de-Stalinization is a shift away from the methods and tools of governance known during the Stalinist period.

${ }^{5}$ F. Thom, Beria. Oprawca bez skazy, translated by K. Antkowiak, Warsaw 2016, Prószyński i S-ka, p. 776. 
the de-Stalinization process. The members of this triumvirate, however, were aware of the large scale of social dissatisfaction resulting from the failure of the entire system. Despite the passage of over 30 years since the Bolshevik takeover of power, the promises of communist ideologists about "heaven on Earth" did not come to fruition. Quite the opposite: the society's living standard was low, the ineffective economy did not produce enough consumer goods, which in turn resulted in permanent shortages of basic foodstuffs, while a huge army and 2.5 million prisoners generated enormous costs, and ubiquitous terror and widespread fear of repression paralyzed any development of the country. According to the head of the Ministry of Internal Affairs, the use of terror of that sort became a threat to the party and the state. ${ }^{6}$ The new leadership resolved, therefore,to do away with the most repressive features of Stalinism in order to reform the system. In the systemic aspect, the "new course"concernedextending the rights of state administration bodies at the expense of party apparatus and federalisation of the country, including the rights of indigenous people. ${ }^{7}$ The changes introduced in the nationalist policy of the USSR consisted, among others, in the restoration of autonomy of certain minorities living in the empire and the principle of appointingactivists from the domestic party apparatus to senior positions in individual republics.

A shift away from mass repression was also initiated, while the powers of the secret police were reduced. Although administrative and criminal law measureswere still in use against the political opponents, this was done on a smaller scale than in previous years. On 27 March, an amnesty was announced, as a result of which some 1.2 million people, or approximately $48 \%$ of convicts were released from labour camps and prisons. Beria ordered a halt to the Gulag huge construction investments, which had taken lives of tens of thousands of people, and interrupted the investigation of the Kremlin physicians accused of conspiracy to murder Soviet leaders. At the beginning of April, torture was officially abolished and stigmatized for "violation of socialist law and order" , and in September the so-called lex Kirov of 1934, which allowed the introduction of ad hoc judicature, rendering judgments in absentia, without the presence of defenders

${ }^{6}$ A. Hilger, op. cit., p. 107. Soviet security police did not, however, completely give up the extra-legal means of pressure.

${ }^{7}$ L. Bazylow, P. Wieczorkiewicz, Historia Rosji, Wrocław 2010, Zakład Narodowy im. Ossolińskich, p. 486.

${ }^{8}$ Soviet security police did not, however, completely give up the extra-legal means of pressure. 
and the chance of appealing. The "new course" reforms were so revolutionary that some of the Soviet comrades formed a conspiracyagainst Beria, headed by one of the triumvirate members, Khrushchev.

The economy was in a dire state. The country was unable to feed itself, the evidence being the fact that Moscow was short of even the basic foodstuffs. It came as no surprise that the reforms concerned also the economic policy: outlays on the development of the electricity and food industries were increased, while fiscal burdens for peasants were reduced, which almost immediately contributed to the elimination of the problem of food shortages in villages and smaller towns. ${ }^{9}$

Following 5 March, the process of de-Stalinization also concerned the Soviet foreign policy, which at that time contributed to the stabilization of the international system. Effective implementation and maintenance of reforms would not have been possible without the relaxation of relations with other countries. In July, the USSR resumed diplomatic relations with Israel, while anti-Yugoslav propaganda was hushed up. On July 27 , a cease-fire was signed in Korea to terminate the largest armed conflict after World War II, having claimed lives of 3 million victims. In August, Prime Minister Malenkov gave a key speech, noting that for the first time since the end of World War II, after a prolonged period of growing tension, there occurred "some defuse of the international atmosphere". "We believe," Prime Minister Malenkov declared, "that there are no objective grounds for clashes between the United States of America and the Soviet Union." ${ }^{10}$ Of significance was the fact that the Soviet prime minister closed his speech mentioning the necessity of building communism only in the USSR, and - unlike the previous Kremlin rulers - all over the world.

The new leadership of the CPSU was also planning to reduce the domination over satellite states and to pursue some staff changes. Pressure was put on communist parties in Eastern Europe to liberalize their internal and foreign policies. Beria instructed communist party leaders in Eastern Europe to mitigate economic policy, especially in relation to workers, peasants, and the middle class. This was a consequence of the threat of a revolt of societies in communist countries, in which - just as in the Soviet Union itself - there prevailed

9 Najnowsza historia świata, t. I: 1945-1963, ed. A. Patek, J. Rydel, J.J. Węc, Kraków 1997, p. 288.

${ }^{10}$ G.M. Malenkow, Przemówienie na V Sesji Rady Najwyższej ZSRR 8 sierpnia 1953 r., Warszawa 1953, p. 40. 
an atmosphere of fear of the authorities' repression and a dire economic situation. This was attributed to costly militarization, collectivization, permanent shortages of consumer goods, too rapid industrialization and expansion of heavy industry against the increasing pauperization of large social strata. The situation in the other countries of the bloc, however, was even harder to control. It was the GDR where the most serious crisis of 1953 broke out.

\section{The uprising behind the "Iron Curtain"}

In the first years of existence of the GDR, the Soviet rule was characterized by elements introduced by communists: strict work discipline, collective farming, expansion of the heavy industry at the expense of the light industry as well as bearing the costs of upkeep of the Soviet army. The deterioration of the economic situation, year after year, the fear of compulsory collectivization, and the confiscation of property resulted in hundreds of thousands of Germans emigrating to West Germany thereby establishing two separate German states. It is estimated that from 1950 to mid-1953, some 800,000 GDR citizens left their homes. In 1953, the communists continued the policy of fighting the Churches. In all the countries subordinated to the Soviets, there ensued the nationalization of church property, while priests were subjected to threats and arrest. On 1 January a ban on teaching religion in school premises in the GDR came into force. A brutal anti-church campaign was also unleashed, targeted especially at the popular Evangelical Young Community (Junge Gemeinde), which was accused of "activities of secret agents" and "espionage". Approximately 3,0oo students were expelled from schools as part of their penalty for their membership in religious communities. ${ }^{11}$

The death of Stalin did not contribute to the liberation of the policies of local communists. On the contrary: on 28 May 1953, the Council of Ministers adopted a regulation raising labour standards by $10 \%$. In the same month, the large metallurgical city of Eisenhüttenstadtchanged its name to "the city of Stalin" (Stalinstadt), which -similarly to the Polish Nowa Huta near Kraków or the Hungarian Sztálinváros - was to be an ideal communist city, free of churches and any encumbrances standing for the "former work values". The Soviets feared that pursuing such a policy could lead to an uncontrolled outbreak of social

${ }^{11}$ J. Tarasiński, Komuniści wobec Kościołów w Niemieckiej Republice Demokratycznej w latach 1949-1978, Toruń 2013, Europejskie Centrum Edukacyjne, p. 120. 
discontent. At the beginning of June, the SED leaders held a discussion in the Soviet politburo, during which they were ordered to introduce a "new course" leading to "healing" of the situation in the GDR. The other communist leaders were repeatedly told that the criticism refers "not to individual countries, but to all people's democracies." ${ }^{12}$ Yet, it was already too late to introduce any changes that would stop the growing uproar of society.

On 16 June, the East Berlin workers- possibly after having been inspired by the activities of Khrushchev and his supporters ${ }^{13}$ - took the plunge and stepped up against the raised labour standards. The following day a general strike began in the capital of the GDR, and numerous protests were observed across the country. Thousands of Germans, encouraged by Stalin's death and certain signs of liberalization, took to the streets of many cities. About half a million people insome 600 plants across the country were on strike, and in the various demonstrations there could have been up to one and a half million people taking part. The protesters saw the announcement of a new course in the party policy as insufficient: they demanded lowering labour standards, reducing food prices and the implementation of political postulates: the resignation of the government and the SED secretary, Walter Ulbricht as well as the introduction of free elections. Thousands of protests were brutally repressed by the Soviet army: over 50 people were killed, while 16 ,ooo were imprisoned. ${ }^{14}$ The situation in this country showed the failure of the communist system as if through a lens: an attempt to control all aspects of social life led to the launching of a revolt. The East German protest against extremely high standards turned into a protest against the entire system.

The revolution in the GDR had yet another victim, to the surprise of many. On 26 June, Khrushchev brought to life the plan to arrest Beria, who was accused, among others, of the liability for the unrest in Eastern Germany and -which was typical of the previous period of government - espionage for the benefit of "imperialism". ${ }^{15}$ The arrest of this most important supporter of de-

12 As cited in: A. Applebaum, Za żelazna kurtyną. Ujarzmienie Europy Wschodniej 19441956, translated by B. Gadomska, Warszawa 2018, Wydawnictwo Agora, p. 496.

13 The stance taken by, to name but one, Professor P. Wieczorkiewicz. See L. Bazylow, P. Wieczorkiewicz, op. cit., p. 487.

14 J. Holzer, op. cit., p. 355.

${ }^{15}$ Malenkov was later to call Beria "the enemy of the nation" and "fierce agent of imperialism" (Idem, op. cit., p. 38). He was also accused of introducing a dictatorship, his actions having been described as "an attempt to put the Ministry of the Interior over the party and government" (A. Hilger, op. cit., p. 56). 
Stalinization and the weakening position of Malenkov affected to a great extent the policy of the Eastern bloc countries. In the Soviet Union, Khrushchev, who at that time was not supportive ofall the "new course" reforms, began to strengthen his grip. However, the changes were not to be withdrawn, with one exception: the possibility of hanging portraits of living communist leaders in public offices was allowed again. Economic reforms were continued: in August, the tax imposed on the peasants was lowered, and in September 1953, Khrushchev announced an increase in the buying-in prices, which resulted in solving problems with the supply of foodstuffs. ${ }^{16}$

The progress of de-Stalinisation in the GDR was slowed down following the arrest of Beria. The reformers were condemned, in turn strengthening the power of Ulbricht, who centralized his control by securing it with the help of the security police. Ulbricht did, however, introduce some of the elements of the "new course", i.e. establishing lower labour standards, raising the standard of living by, for instance, reducing prices of foodstuffs in October 1953 and introducing more a subtle repression of the Churches. ${ }^{17}$

\section{The rule and restriction of the power of "Stalin's best pupil"}

During Stalinism, the Hungarian society was subjected to enormous repression. The then leader MátyásRákosi, termed "the best pupil of Stalin" found terror to be an obvious way of exercising power. In the years 1948-1953, the number of convicts ranged from 700,000 to 800,000 people. ${ }^{18}$ They were sent to prisons, labour camps, or internment camps. The economic situation of the state - similarly to other countries in that region - was dire. Despite gigantic expenditures on investments, the population's standard of living was dropping year after year. These problems were compounded by the fact that Hungary had to pay huge war reparations to the USSR. It is estimated that as late as 1953, 70\% of industrial output went to the Soviet Union. ${ }^{19}$

16 R. Pichoja, Historia władzy w Związku Radzieckim 1945-1991, translated by Michał Głuszkowski, Piotr Zemszał, Warszawa 2011, Wydawnictwo Naukowe PWN, p. 134.

17 See J. Tarasiński, op.cit., p. 126-127.

${ }^{18}$ K. Bartosek, Europa Środkowa i Południowo-Wschodnia, in: Czarna ksiega komunizmu. Zbrodnie, terror, prześladowania, ed. S. Courtois et al., Warszawa 1999, Prószyński i S-ka, p. 390.

19 R. Service, Towarzysze. Komunizm od poczatku do upadku. Historia zbrodniczej ideologii, translated by Hanna Szczerkowska, Kraków 2008, Wydawnictwo Znak, p. 375. 
Similarly to the GDR, the death of Stalin did not affect immediate changes in the Hungary's policy. This took place only after the July visit of the Hungarian communists to Moscow. "Horrified" by the crimes and terror, but also by the possibility of losing their influence in Budapest, the Russians demanded that Hungarian comrades would refrain from the use of mass terror, rehabilitate the repressed and introduce changes in the economic activity. Rákosi was forced to change the course of the policies of the time, as well as to make a statement expressing self-criticism at the meeting of the Central Committee, which adopted a resolution on the "distortion of socialism", and finally to resign from the post of prime minister. ${ }^{20}$ Similar staff changes occurred in all countries of the region. The communists, accustomed to concentrating several positions in their hands, were now faced with a choice: they would either retain power over the party or over the government.

The new Hungarian Prime Minister was Imre Nagy, a supporter of more liberal methods of exercising power, who mitigated the "ruthlessness and nonsense of Stalinism"21 by announcing a partial amnesty and rehabilitating many victims. Nagy liquidated forced labour camps and ad hoc courts, stopped hasty industrialization, raised wages and - similar to the USSR - the production of consumer goods. Over $1 / 3$ of peasants exercised their right to withdraw from agricultural cooperatives. Culture also developed during Nagy's rule. Launching the changes in question was meant to eliminate the atmosphere of terror and to improve the difficult economic situation of the country. As long as Nagy enjoyed the support of Moscow, certain de-Stalinization processes were not threatened - despite constant attacks of Rákosi and his supporters. The situation lasted until the beginning of 1955 .

De-stalinization in Hungary, however, did not cover all aspects of social life. Initiated in Moscow, the "new course" policy did not include religious freedom, nor did it affect the relations with the Hungarian religious communities. The rulers continued their hostile policy against the Church. The question of staffing the key positions in the Church was of utmost importance. In 1953, the decree on the influence of the State Council on the appointment of senior clerical functions had already been in effect for two years. That year, the most important clergy were confined in Stalinist prisons: the Primate of Hungary,

\footnotetext{
${ }^{20}$ He did, however, retain the function of the first secretary of the Hungarian Workers' Party (MDP).

${ }^{21}$ I. Romsics, op. cit., p. 388.
} 
cardinal Mindszenty, who, in 1949, following a brutal investigation received a life sentence for "high treason" and "espionage"; his successor holding the position of the chairman of the Conference of the Hungarian Episcopate, Archbishop József Grösz and György Bulányi, who had created an underground church, in the opposition against the pro-government movement of "priests of peace”. Hence, Hungarian Catholics were to wait for any changes in the state-Church relationship for three more years.

\section{The origins and course of protests in Czechoslovakia}

The early 1953saw the reforms of the "thaw" as inevitable and spanning all communist bloc countries. However, not all the countries in question followed the model set by the USSR. In Czechoslovakia, in the month of Stalin's death there occurred a change of power: the first secretary of the Central Committee of the Communist Party of Czechoslovakia (KSČ) was Antonín Novotný, the president - Antonin Zápatocký, and the head of government - Viliam Široký. The shifts of the key positions in the state did not mean a radical departure from the totalitarian methods of exercising power. The amnesty of early May 1953 did not include political prisoners, and a year later, in the Bratislava court there a show was put on - a case trial in which sentences of long-term imprisonment, including life sentences, were rendered. ${ }^{22}$ In 1953, Bohumil Laušman, the former chairman of social democracy was abducted in Austria, spending the following ten years in prison.

Similarly to Hungary, repression was maintained against the Catholic Church, which, since 1950, had been functioning without male religious orders, education, or the press. A year later, almost all bishops from the Czech, Moravia, and Slovakia were arrested. The phase of the harshest repression came to an end in 1952, when the Church, both in the Czech and Slovakia, was entirely broken. ${ }^{23}$ This dramatic situation may be evidenced by the fact that in 1953 (until 1965) only

${ }^{22}$ The first amnesty for political prisoners in Czechoslovakia took place only in 1960(see J. Cuhra, Dyskusja. Zróżnicowanie represji wobec duchowieństwa w krajach byłego bloku wschodniego w okresie stalinowskim, w: Represje wobec duchowieństwa..., p. 86).

${ }^{23}$ A. Grajewski, Chronologia i historyczne uwarunkowania represji wobec duchowieństwa katolickiego w krajach Europy Środkowej, in: Represje wobec..., p. 26. 
one bishop, Antonin Eltschner, pursued religious activity in the Czech lands. ${ }^{24}$ In that year, the Czechoslovak communists undertook the last actions towards religious communities, in order to establish the already introduced changes and undertook a large-scale propaganda campaign to reconcile the public with its policy. ${ }^{25}$ Any reforms which were introduced in Czechoslovakia in the spirit of Beria's "new course", were in fact merely a cosmetic amendment. Despite the dismissal of Karel Bacílek, minister of public security, he was entrusted with a high party position.

Similarly to the other people's democratic countries, the country's economic situation was dramatic: inflation was rampant and the living standard of the population was at a very low level. On 30 May 1953, the government of Viliam Široki made a disastrous decision to introduce a currency reform that in fact liquidated a large portion of citizens' savings and reduced their wages. Following this, the public gave vent to their dissatisfaction by organizing numerous demonstrations, including in Pilsen, Prague, Trinec, Brno and mines in the Ostrava region. Free elections were demanded during public speeches. The largest rebellion took place on 1 June in Pilzno, where some 20,000 employees of the Škoda plant went on strike. The demonstrators took over the seat of the city authorities, burnt the Soviet flags, and tore the portraits of communist leaders to pieces. The clashes with security forces led to, according to official data, six casualties.

\section{The Stalinist rule in Romania and Bulgaria}

After Stalin's death, the reforms were also announced in Romania - a country where the repressions during the Stalinist period were extremely cruel. The distinguishing element for the terror system in Romania was the use of "brainwashing" methods, once known in Asia, such as torturing prisoners by other prisoners. As early as 4 April 1953, an amnesty was adopted, the earliest event taken place from all countries of the communist bloc. There had also been some liberalization of economic policy which consisted in taking greater account of the growing consumer needs of the society and the temporary suspension of collectivization.

${ }^{24}$ J. Cuhra, Represje wobec duchownych i wiernych na ziemiach czeskich w latach 1948-1962, in: Represje wobec..., p. 55.

25 See A. Grajewski, op. cit., p. 26. 
On 18 July 1953, the construction of the Danube Canal - Black Sea, which had begun four years earlier, was stopped, the canal having been intended to ease the transport of ships up the River Danube in the event of an armed conflict with Yugoslavia. Because of the huge sacrifices associated with its construction, it was termed the "death channel" or "tomb of the Romanian bourgeois". At the August Plenum of the Central Committee, Gheorghe Gheorghiu-Dej criticized manifestations of the cult of the individual. The above changes, which to some extent formed part of the de-Stalinization processes, did not mean that severe repression against political opponents would stop, as evidenced by the 1954 execution of Lucretiu Pătrăşcanu, the former Minister of Justice.

In 1953, the Bulgarian Communist Party was led by ValkoChervenkov, who following the death of Stalin initiated liberalization of the economy. In many respects, Bulgaria resembled another Soviet republic. The Bulgarian Ambassador in Moscow was ex officio the Minister of Government in Sofia, and the Ambassador of the USSR was openly accompanying the key persons in the state during important events. ${ }^{26}$ In May 1953, protests of tobacco factory workers took place in Plovdiv, the incident having particularly alarmed the Kremlin leadership since until then the Bulgarian society had not taken such strong a stance against the communist authorities. ${ }^{27}$ The "new course" meant - according to suggestions from Moscow - the need for collective management, criticism of past mistakes, and in the economy - the reduction of the output of heavy industry for the benefit of consumer products and farming produce. 9 September marking the anniversary of "liberation", an amnesty was granted, releasing 10,oooperson from prisons and camps. The foreign policy of this country was also relaxed. At the end of 1953 an agreement on trade with Greece was signed, after a serious border dispute had taken place a year earlier as a result of the occupation by the Bulgarian army of two islands on the Marica River. Both in Romania and Bulgaria, the "new course" reforms were introduced by Stalinists, who in the turbulent year of 1953 managed to retain power.

${ }^{26}$ B. Jelavich, Historia Bałkanów, v. II: wiek XX, translated by Marek Chojnacki, Justyn Hunia, Kraków 2005, Wydawnictwo Uniwersytetu Jagiellońskiego, p. 382.

27 As cited in: A. Applebaum, Za żelazną kurtyna..., p. 494. 


\section{Conclusion}

In 1953, it transpired that, contrary to ideological claims, the Soviet bloc was, in fact, not a monolith, and the differences in pursuing policies by individual communist states were becoming ever more apparent. The leaders of some of these countries believed that certain system reforms should be introduced. Amongst them were the USSR and Bulgaria, somewhat later Romania and - following a visit to the Kremlin of the MDP communist party leaders - Hungary. The GDR communists did not manage to implement the large scale reforms postulated by the Soviets due to their own dislike of the "new course" and the outbreak of the rebellion on 16 June. However, in no country was de-Stalinization to cover all aspects of social life. An example is the religious policy in Poland, Czechoslovakia, and Hungary, where the atheization of the country was carried out using ruthless repression against the Churches. De-Stalinization was introduced for fear of losing the power. The "new course" concerned those aspects of policy which would enable the communists to wield unrestricted power in the societies which - to the surprise of the communists - were to show resistance against the influence of propaganda and the economic "successes" of the new system. The processes of de-Stalinization initiated in some countries did not, of course, mean that the USSR would forego its domination over the entire communist states' bloc.

Not all of the discussed communist states followed the Soviet Union model. Some leaders stalled taking the decision on introducing reforms, awaiting the final outcome of the fight for the Stalin's legacy. They were hoping that the liberalization of the party policy taking place in Crimea was only temporary and soon the old and proven methods would be back in place. Czechoslovakia, the German Democratic Republic, and Poland were, to a limited extent, implementing the "new course" reforms, while in many cases still applying the instruments of governance characteristic of the Stalin era.

Accelerated de-Stalinization in some of the communist countries lasted until mid-1953. During this time, rebellions in various forms and of various levels of intensity broke out in Eastern Europe, while the conflict between Stalinists and their opponents would continue to grow. The breakthrough was marked by the outbreak of the uprising in the GDR. The new Kremlin leadership shirked the responsibility for these events onto their predecessors, thus leading to the arrest of the once powerful Beria. Removing and then killing this key supporter of changes lead to a significant decline in the enthusiasm 
of the reformers across the entire Soviet bloc. However, this could not prevent the launch of de-Stalinization in a long-term perspective, because in all Eastern European countries, social discontent due to mass terror, sovietization, forced collectivization, and inefficient consumer industry would soar to high levels. The new Kremlin ruler, although in 1953 had opposed radical settlements with the Stalin rule, could not stop the necessary reforms. For another significant event one would have to wait three more years, until the 2oth Congress of the Communist Party when Khrushchev himself - already openly and casting no doubt - took a stance against Stalin, criticizing the cult of the individual.

\section{Bibliography}

ApplebaumA., Gułag, translated by Jakub Urbański, Warsaw 2018, Wydawnictwo Agora. Applebaum A., Za żelazną kurtynq. Ujarzmienie Europy Wschodniej 1944-1956,translated by Barbara Gadomska, Warszawa 2018, Wydawnictwo Agora.

Bazylow L., Wieczorkiewicz Paweł, Historia Rosji, Wrocław 2010, Zakład Narodowy im. Ossolińskich.

Besier G., Stokłosa Katarzyna, Europa dyktatur, translated by Joanna Hashold, Warszawa 2009, PWN.

Czarna księga komunizmu. Zbrodnie, terror, prześladowania, ed.S. Courtois et al., Warszawa 1999, Prószyński i S-ka.

Czekiści. organy bezpieczeństwa w europejskich krajach bloku sowieckiego 1944-1989, ed.K. Persak, Ł. Kamiński, Warszawa 2010, Instytut Pamięci Narodowej.

Holzer J., Europa zimnej wojny, Kraków 2012, Wydawnictwo Znak.

Jelavich B., Historia Bałkanów, t. II: wiek XX, translated by Marek Chojnacki, Justyn Hunia, Kraków 2005, Wydawnictwo Uniwersytetu Jagiellońskiego.

Malenkow G.M., Przemówienie na V Sesji Rady Najwyższej ZSRR 8 sierpnia 1953 r., Warszawa 1953, Książka i Wiedza.

Najnowsza historia świata, t. I: 1945-1963, ed. A. Patek, J. Rydel, J.J. Węc, Kraków 1997.

Pichoja R., Historia władzy w Związku Radzieckim 1945-1991, translated by Michał Głuszkowski, Piotr Zemszał, Warszawa 2011, Wydawnictwo Naukowe PWN.

Represje wobec duchowieństwa Kościołów chrześcijańskich wokresie stalinowskim w krajach byłego bloku wschodniego, ed.J. Myszor, A. Dziurok, Katowice 2004, Wydział Teologiczny Uniwersytetu Śląskiego, Instytut Pamięci Narodowej.

RomsicsI., Historia Węier, translated by Agnieszka Barszczewska, Szymon Brzeziński, Maciej Sagata, Poznań 2018, Media Rodzina.

Service R., Towarzysze. Komunizm od początku do upadku. Historia zbrodniczej ideologii, translated by Hanna Szczerkowska, Kraków 2008, Wydawnictwo Znak. 
Tarasiński J., Komuniści wobec Kościołów w Niemieckiej Republice Demokratycznej w latach 1949-1978, Toruń 2013, The European Education Centre.

Vladimir T., Stalinizm na każda okazję. Polityczna historia rumuńskiego komunizmu, translated by Piotr Nowakowski, Kraków 2010, Universitas.

ThomF., Beria. Oprawca bez skazy, translated by Krystyna Antkowiak, Warszawa 2016, Prószyński i S-ka. 